\title{
ANALISIS WILLINGNESS TO PAY PENGGUNA HIPPAM CANGAR TERHADAP MATA AIR GEMULO
}

\section{ANALYSIS OF WILLINGNESS TO PAY HIPPAM CANGAR CONSUM- ER FOR GEMULO SPRING}

\author{
Hardian Cahya Ningrum \\ Fakultas Ekonomi dan Bisnis, Universitas Brawijaya, Jl. Mayjen Haryono 165 Malang \\ chaa.chaaa@ymail.com
}

\begin{abstract}
ABSTRAK
Penurunan kualitas dan kuantitas air disebabkan oleh pemanfaatan mata air secara berlebihan sehingga akan berdampak pada ketersediaan air dalam jangka panjang. Jika hal itu terjadi, air sebagai aset lingkungan akan mengalami kenaikan harga dan tidak lagi dapat dikonsumsi secara bebas. Mata air Gemulo merupakan satu-satunya sumber air yang dimanfaatkan oleh masyarakat Dusun Cangar melalui jasa HIPPAM Cangar. Untuk menjaga kelestarian mata air Gemulo diperlukan suatu sistem insentif, yaitu dengan penerapan harga air yang tepat (the right price) dan kelembagaan yang benar (the right institution). Tujuan penelitian ini adalah: menghitung besarnya nilai Willingness to Pay (WTP) dan total nilai WTP, sertamenganalisis variabel-variabelyang mempengaruhi nilai WTP pelanggan HIPPAM Dusun Cangar sebagai pemanfaat mata air Gemulo. Analisis yang digunakan adalah Contingent Valuation Method (CVM) dan regresi linier. Hasil penelitian menunjukkan bahwa perkiraan nilai WTP adalah Rp 17.950 untuk tiap kepala keluarga per bulan dan nilai total WTP adalah Rp 8.243.050 per bulan; Variabel-variabel yang berpengaruh terhadap nilai WTP masyarakat Dusun Cangar adalah jumlah kebutuhan air (KA) dan biaya kebutuhan air (BA).
\end{abstract}

Kata kunci: kelestarian mata air, pengelolaan HIPPAM, contingent valuation method, Willingness to Pay

Klasifikasi JEL: C39, Q53

\section{ABSTRACT}

Decresing in water quality and quantity are caused by excessive use of water springs, which have an impact on long-term supply of water. If it happens water as an environmental asset will increase in price and can no longer be consumed freely. Gemulo spring is the only source of water utilized by the people of Dusun Cangar through HIPPAM Cangar services. Gemulo spring requires an incentive system, namely by applying the right water price and the right institution. The purpose of this research is: calculate the value of Willingness to Pay (WTP) and the total value of WTP, (2) analyze the variables affecting the value of WTP HIPPAM customers Dusun Cangar as the beneficiary of Gemulo springs. This analysis uses Contingent Valuation Method and linear regression. The results are (1) Estimated value of WTP is Rp 17,950 a month and total WTP value is Rp 8,243,050 a month; (2) The variables that influence the value of WTP of Cangar community is the amount of water demand (KA) and the cost of water needs $(B A)$.

Keywords: Spring Sustainability, HIPPAM Management, Contingent Valuation Method, Willingness to Pay

JEL Classification: C39, Q53 


\section{PENDAHULUAN}

Sumber daya air merupakan salah satu potensi sumber daya alam yang memiliki peran penting sebagai kebutuhan dasar yang harus dipenuhi untuk kelangsungan hidup manusia. Terjadinya peningkatan maupun penurunan kualitas dan kuantitas air berkaitan dengan pengelolaan di daerah hulu, dimana daerah hulu berperan sebagai daerah tangkapan air (catchment area) yang bertugas menampung air ke dalam tanah. Selain itu, pembangunan di sektor ekonomi dan pertambahan penduduk dapat berdampak terhadap keberadaan daerah hulu. Kondisi ini akan berdampak terhadap supply air bersih ke masyarakat.

Mata air Gemulo merupakan salah satu mata air di Kota Batu yang memiliki debit air sebesar 116,21 liter/detik dan terletak di aliran sungai dari Gunung Arjuno dan mengaliri empat desa, yaitu Desa Bulukerto, Desa Bumiaji, Desa Pandanrejo, dan Desa Sidomulyo. Mata air Gemulo dimanfaatkan untuk melayani kebutuhan air domestik atau rumah tangga (mandi, masak, cuci dan kakus), serta mengairi perkebunan warga, baik untuk tanaman hias, sayuran, dan buah-buahan selain itu juga dimanfaatkan oleh PDAM Kota Batu.

Dusun Cangar Desa Bulukerto merupakan dusun yang terletak satu kilometer dari titik mata air Gemulo dan merupakan daerah pelayanan terdekat dari lokasi mata air. Untuk pemenuhan kebutuhan air bersih, semua warga Dusun Cangar menggunakan jasa HIPPAM yang memanfaatkan air dari mata air Gemulo. HIPPAM adalah himpunan penduduk pemakai air minum yang bergerak di bidang penyediaan air minum khususnya di wilayah pedesaan. HIPPAM terbentuk dari kelompok masyarakat yang peduli terhadap kebutuhan air bersih warga desa, biasanya anggota HIPPAM terdiri dari tokoh masyarakat dan warga desa setempat. HIPPAM menjadi satu-satunya alternatif warga Dusun Cangar untuk mendapatkan akses air bersih, karena tidak ada layanan PDAM yang masuk ke Dusun Cangar.Fenomena ini disebabkan oleh kondisi geografis Dusun Cangar yang terletak di dataran tinggi dengan kontur yang curam sehingga PDAM mengalami kendala dalam pemasangan saluran. Selain itu, keberadaan HIPPAM yang terbentuk lebih awal daripada PDAM membuat PDAM enggan untuk beroperasi di wilayah tersebut, hal ini juga yang menyebabkan warga sulit untuk membuat sumur.

Untuk menjaga kelestarian lingkungan mata air diperlukan suatu sistem insentif bagi kondisi tersebut. Sistem insentif yang dimaksud adalah untuk menghemat air berupa penerapan harga air yang tepat (the right price) dan didukung oleh sistem kelembagaan yang benar (the right institution) (Dasrizal , 2012). Peningkatan jumlah penduduk dan pendapatan masyarakat telah mengakibatkan peningkatan terhadap permintaan (demand) terhadap air bersih. Sehingga konsumsi air juga akan menjadi meningkat.

Berdasarkan hasil observasi awal tarif air yang ditetapkan oleh HIPPAM Cangar sebesar Rp. 200/ $\mathrm{m}^{3}$ untuk pemakaian $1-15 \mathrm{~m}^{3}$ pertama. Tarif tersebut merupakan kesepakatan bersama yang terbentuk melalui musyawarah anggota HIPPAM dengan tokoh masyarakat dan warga sekitar. Tarif ini tentu jauh lebih murah dibanding dengan tarif dasar yang ditetapkan oleh PDAM yaitu sebesar Rp. $880 / \mathrm{m}^{3}$. Menurut penelitian Masduqi (2008) keterbatasan kemampuan pengelola HIPPAM, terletak pada masalah sumber daya, administrasi dan pendanaan, hal tersebut dapat mempengaruhi keandalan sistem penyediaan air bersih di perdesaan. Dengan murahnya tarif tersebut membuat HIPPAM mengalami keterbatasan dana untuk kebutuhan operasional HIPPAM secara rutin. Adanya keterbatasan dalam hal pendanaan akan berdampak terhadap upaya konservasi mata air Gemulo yang belum dapat terealisasi dengan baik.

Kondisi tersebut menjadi pendorong apakah nilai iuran yang diterapkan telah sesuai dengan kesediaan pelanggan atau belum, apakah alasan masyarakat bersedia membayar hanya karena melaksanakan kewajiban atau benar-benar merasa bahwa keberadaan HIPPAM dan mata air penting bagi keberlanjutan ketersediaan air, sehingga dianggap penting untuk meneliti kesediaan membayar (Willingness to Pay / WTP) masingmasing individu. Jika pengelolaan HIPPAM baik akan dapat memberikan dampak positif terhadap kelestarian mata air Gemulo dan supply air bersih ke pelanggan dapat lebih terjamin kualitas, kuantitas dan kuantitasnya dengan baik pula. 
Tujuan dari penelitian ini adalah untuk mengetahui besarnya nilai kesediaan membayar (Willingness to Pay / WTP) responden terhadap pemanfaatan mata air Gemulo oleh HIPPAM Dusun Cangar dan Mengetahui faktor-faktor saja yang mempengaruhi nilai (Willingness to Pay / WTP) responden terhadap pemanfaatan mata air Gemulo oleh HIPPAM Dusun Cangar.

\section{TINJAUAN PUSTAKA}

\section{Hubungan Ekonomi dengan Sumber Daya Alam dan Lingkungan}

Menurut Fauzi (2004), sumber daya alam merupakan barang ekonomi khusus (special economic goods) karena berbeda dengan modal buatan, sumber daya alam tidak dihasilkan oleh manusia, sehingga sering disebut sebagai trully gift of nature (anugerah alam). Jika dimanfaatkan dengan baik, sumber daya alam dan jasa lingkungan yang dihasilkan akan memberikan manfaat yang dapat ditransformasikan ke dalam bentuk kemakmuran lainnya. Sedangkan pola pengelolaan sumber daya alam yang kurang berkelanjutan berpotensi menimbulkan kerugian ekonomi yang cukup signifikan, sehingga dapat mengurangi manfaat dari suatu pembangunan.

Suparmoko (1994) menyatakan adanya ketidaksamaan antara pertumbuhan ekonomi dengan ketersediaan sumber daya alam, dan pertumbuhan ekonomi dengan ketersediaan barang untuk proses produksi. Semakin cepat pertumbuhan ekonomi maka sumberdaya yang dibutuhkan untuk produksi juga semakin banyak sehingga dapat mengurangi stock sumberdaya alam yang tersedia di bumi.

\section{Permintaan dan Penawaran Sumber Daya Air}

Kebutuhan air bersih (demand) memiliki kecenderungan meningkat seiring semakin besarnya jumlah penduduk dan pertumbuhan kegiatan ekonomi. Untuk memenuhi kebutuhan yang semakin meningkat, sumber air permukaan dan air tanah diambil dengan berbagai cara dan upaya, baik yang konvensional maupun dengan teknologi. Penggunaan cara pengeksploitasian sumberdaya air yang mengakibatkan rusaknya keseimbangan sumber daya alam lainnya. Penurunan kualitas air ini tidak hanya terjadi pada sumber air tanah tetapi juga pada sumber air permukaan. Kerusakan ini berdampak pada keterbatasan supply air akibat jumlah air yang tersedia menjadi berkurang karena sedikitnya air yang masuk ke dalam akuifer dan banyaknya bahan pencemar yang dapat mengakibatkan penurunan air tanah dan air permukaan (Rizal, 2010)

Kelangkaan sumber daya air pada gilirannya meningkatkan nilai atau harga air bersih sehingga terciptanya sejumlah biaya atas pemanfaatannya. Keterbatasan supply baik akibat terbatasnya daya dukung alam atau semakin meningkatkan permintaan (demand) menimbulkan terciptanya biaya yang harus dibayar oleh konsumen atas sejumlah air bersih yang dibutuhkan. Apabila semakin banyaknya permintaan akan air bersih, sedangkan jumlah yang tersedia jumlahnya sangat terbatas. Maka dapat dipastikan harga air akan menjadi mahal, padahal pertumbuhan perekonomian belum tentu secepat pertumbuhan harga air tersebut. Jika ini terjadi, maka dapat dipastikan bahwa tingkat kesejahteraan masyarakat akan semakin berkurang mengingat proporsi pendapatan yang dibelanjakan untuk konsumsi air semakin meningkat sehingga mengurangi kemampuan mengkonsumsi barang lainnya.

Masalah air bersih dapat menjadi masalah yang kompleks di masa depan. Permintaan air akan terus meningkat, sementara supply air yang konstan dan cenderung berkurang, serta pertambahan penduduk yang tinggi akan menimbulkan ketidakseimbangan antara supply dan demand. Ketidakseimbangan tersebut dapat diatasi dengan melakukan pengendalian tingkat pencemaran dan perusakan sumber-sumber air bersih. Sehingga diperlukan adanya konservasi sumber daya air dan penerapan dalam manajemen pengelolaan air bersih yang berkelanjutan.

\section{METODE PENELITIAN}

Penelitian dilaksanakan di Dusun Cangar, Desa Bulukerto, Kecamatan Bumiaji, Kota Batu, Jawa Timur. Pemilihan lokasi ini dilakukan secara sengaja (purposive) dengan pertimbangan bahwa di lokasi tersebut merupakan lokasi pertama pelayana mata air Gemulo dan terletak paling 
dekat dengan mata air, yakni satu kilometer dari lokasi titik mata air.

Data yang digunakan meliputi data primer dan data sekunder. Data primer diperoleh melalui kuesioner dan wawancara langsung secara mendalam (indepth interview) dengan responden dan pengurus HIPPAM. Data sekunder meliputi data sosial demografis penduduk Dusun Cangar serta data dari beberapa instansi yang terkait dengan pengelolaan upaya konservasi mata air Gemulo.

Teknik pengambilan sampel dalam penelitian ini dilakukan dengan teknik convenience sampling yaitu pengambilan responden yang mudah ditemui dan mempunyai kemampuan sebagai responden (Nazir, 1988) dengan pertimbangan secara sengaja rumah tangga mana yang menggunakan jasa HIPPAM Cangar untuk memenuhi kebutuhan rumah tangganya. Responden yang diambil pada penelitian ini berjumlah 45 responden dari total populasi sebanyak 447 Kepala Keluarga yang terdapat di Dusun Cangar.

\section{Variabel Penelitian}

Berikut ini merupakan beberapa variabel yang digunakan dalam penelitian:

1. Jumlah Pengguna Air (PA)

Jumlah Pengguna Air dalam rumah tangga, merupakan banyaknya anggota keluarga yang memanfaatkan air dalam satu rumah tangga. Dengan mengetahui jumlah pengguna air dalam satu rumah tangga maka akan diperoleh fluktuasi pemakaian air dalam rumah tangga tersebut.

2. Jumlah Kebutuhan Air (KA)

Jumlah kebutuhan air, untuk menggambarkan seberapa besar pemakaian air setiap orang setiap harinya. Jumlah kebutuhan air perlu diketahui karena adanya perbedaan kebutuhan air untuk tiap individu dalam satu rumah tangga.

3. Tingkat Pendidikan (TP)

Variabel pendidikan digunakan sebagai variabel yang memiliki keterkaitan dengan pemakaian air karena terkait dengan pengetahuan tentang standar kesehatan dan kebersihan seluruh anggota keluarga. Selain itu variabel ini dinilai berpengaruh karena umumnya masyarakat dengan tingkat pendidikan lebih baik cenderung lebih memahami nilai ekonomi dari sumberdaya yang semakin lama semakin terbatas jumlahnya dan menjadi barang ekonomi akibat kelangkaan yang terjadi.

4. Rata-Rata Pendapatan (RPRT)

Variabel pendapatan digunakan sebagai variabel yang memiliki keterkaitan dengan pemakaian air juga karena diduga terkait dengan jenis alat-alat rumah tangga yang digunakan oleh rumah tangga serta kemampuannya untuk memenuhi kebutuhan akan air bersih. Tingkat pendapatan responden sangat berpengaruh terhadap besarnya nilai WTP yang ingin dibayarkan oleh masyarakat untuk iuran air. Hal ini erat kaitannya dengan kemampuan ekonomi masyarakat dalam membayar biaya penggunaan air yang dikonsumsinya sehari-hari.

5. Biaya Kebutuhan Air (BA)

Adalah biaya yang dikeluarkan tiap rumah tangga secara rutin untuk kebutuhan air, yang dihitung berdasarkan jumlah pemakaian air tiap bulannya. Dalam penelitian ini tiap rumah tangga membayar iuran rutin ke HIPPAM sebagai penyedia air bersih untuk warga. Biaya kebutuhan air digunakan sebagai tolak ukur kemampuan warga untuk kesanggupan membayar nilai WTP yang akan diajukan dalam pertanyaan berikutnya.

\section{Analisis Nilai WTP Responden terhadap Pemanfaatan Mata Air Gemulo}

Untuk mengetahui nilai WTP responden terhadap pemanfaatan mata air Gemulo yaitu dengan melakukan tahapan CVM dan melakukan analisis fungsi WTP dengan menggunakan regresi berganda.

\section{A. Tahap Menggunakan CVM}

Tahap-tahap dalam melakukan penelitian untuk menentukan WTP dengan menggunakan CVM dalam penelitian ini meliputi (Hanley dan Spash, 1993)

\section{Membuat Pasar Hipotetik (Setting Up the Hypotetical Market)}

Pasar hipotetik dibentuk atas dasar munculnya ancaman penurunan kualitas dan kuantitas mata air Gemulo akibat terjadinya pembangunan yang tidak memperhatikan kelestarian lingkungan. Selain itu pemanfaatan mata air 
Gemulo oleh banyak pihak, diantaranya adalah HIPPAM dan PDAM Kota Batu membutuhkan kontinuitas dalam jangka panjang agar supply air ke pelanggan dapat terjamin dengan baik. Dengan skenario tersebut responden dapat mengetahui gambaran tentang situasi hipotetik mengenai rencana konservasi untuk pelestarian mata air Gemulo.

2. Mendapatkan Penawaran Besarnya Nilai WTP (Obtaining Bids)

Survei dilakukan dengan melakukan wawancara langsung pada responden. Teknik yang digunakan dalam mendapatkan nilai penawaran pada penelitian ini dilakukan dengan menggunakan metode dichotomous choice yaitu menawarkan kepada responden sejumlah uang tertentu dan menanyakan apakah responden mau membayar atau tidak sejumlah uang tersebut untuk memperoleh perbaikan kualitas lingkungan melalui pembayaran jasa lingkungan.

3. Memperkirakan Nilai Rata-Rata WTP (Calculating Average WTP)

WTPi dapat diduga dengan melakukan nilai rata-rata dari penjumlahan keseluruhan nilai WTP dibagi dengan jumlah responden. Dugaan rataan WTP dibagi dengan rumus :

$$
E W T P=\sum_{i=1}^{n} W i P f i
$$

Dimana

$\mathrm{EWTP}=$ Dugaan rataan WTP

$\mathrm{Wi}=$ Nilai WTP ke-i

Pfi $=$ Frekuensi Relatif

$\mathrm{n}=$ Jumlah responden

$\mathrm{i}=$ Responden ke-i yang bersedia melakukan pembayaran iuran

4. Memperkirakan Kurva WTP (Estimating Bid Curve)

Pendugaan kurva akan dilakukan dengan mengunakan persamaan sebagai berikut :

$W T P=f(P A, K A, T P, B A, R P R T)$

Dimana :

WTP $=$ Nilai WTP responden $(\mathrm{Rp} /$ bulan $)$

$\mathrm{PA}=$ Jumlah pengguna air (orang)

$\mathrm{KA}=$ Jumlah kebutuhan air $\left(\mathrm{m}^{3} /\right.$ hari $)$
$\mathrm{TP}=$ Tingkat pendidikan

$\mathrm{BA}=$ Biaya kebutuhan air (Rp/bulan)

$\mathrm{RPRT}=$ Rata-rata pendapatan (Rp/bulan)

5. Menjumlahkan Data (Agregating Data)

Penjumlahan data merupakan proses dimana nilai tengah penawaran dikonversikan terhadap total populasi yang dimaksud. Setelah menduga nilai tengah WTP maka dapat di duga nilai WTP dari rumah tangga dengan menggunakan rumus :

$$
T W T P=\sum_{i=1}^{n} W T P i\left(\frac{n i}{N}\right) P
$$

dimana :

$\begin{array}{lll}\text { TWTP } & = & \text { Total WTP } \\ \text { WTPi } & = & \text { WTP individu sampel } \\ \text { ke-i } & & \\ \text { ni }= & \text { Jumlah sampel ke-i yang bersedia } \\ \text { membayar } & \text { sebesar WTP } \\ \mathrm{N}= & \text { Jumlah sampel } \\ \mathrm{P}= & \text { Jumlah populasi } \\ \mathrm{i}= & \text { Responden ke-i yang } & \text { bersedia } \\ \text { membayar pembayaran iuran } & \end{array}$

6. Mengevaluasi Penggunaan CVM (Evaluating the CVM Exercise)

Tahap ini dilakukan untuk mengetahui tingkat keberhasilan pengaplikasian CVM. Untuk mengevaluasi pelaksanaan model CVM dilihat tingkat keandalan (reability) fungsi WTP. Uji yang dapat dilakukan dengan uji keandalan yang melihat nilai $\mathrm{R}^{2}$ dari model OLS (Ordinary Least Square) WTP.

\section{B. Analisis Fungsi WTP}

Analisis ini digunakan untuk mengetahui faktorfaktor yang mempengaruhi WTP responden. Model yang digunakan adalah model regresi linier berganda. Persamaan regresi besarnya nilai WTP dalam penelitian ini adalah sebagai berikut :

$$
\begin{aligned}
& \mathrm{WTP}=\beta_{0}+\beta_{1} \mathrm{PA}_{\mathrm{i}}+\beta_{2} \mathrm{KA}_{\mathrm{i}}+\beta_{3} \mathrm{TP} \\
& +\beta_{4} \mathrm{BA}_{\mathrm{i}}+\beta_{5} \mathrm{RPRT}_{\mathrm{i}}+\varepsilon_{\mathrm{i}}
\end{aligned}
$$




$$
\begin{array}{ll}
\mathrm{KA} & =\text { Jumlah kebutuhan air }\left(\mathrm{m}^{3} / \text { hari }\right) \\
\mathrm{TP} & =\text { Tingkat pendidikan } \\
\mathrm{BA} & =\text { Biaya kebutuhan air }(\mathrm{Rp} / \text { bulan }) \\
\mathrm{RPRT} & =\text { Rata-rata pendapatan }(\mathrm{Rp} / \text { bulan }) \\
\mathrm{i} & =\text { Responden ke-i }(\mathrm{i}=1,2, \ldots ., \mathrm{n}) \\
\varepsilon & =\text { Galat }
\end{array}
$$

Variabel-variabel tersebut dipilih berdasarkan teori-teori dan observasi langsung di lokasi penelitian. Besarnya nilai WTP penerima manfaat dipengaruhi oleh faktor-faktor sebagai berikut: jumlah pengguna air, jumlah kebutuhan air, tingkat pendidikan, biaya kebutuhan air dan rata-rata pendapatan.

\section{HASIL DAN PEMBAHASAN}

\section{Jenis Kelamin Responden}

Mayoritas responden yang termasuk dalam survei ini adalah perempuan yaitu sebanyak $82,2 \%$. Perbandingan responden laki-laki dan perempuan dapat dilihat pada Tabel 1.

Tabel 1. Data Jumlah Responden berdasarkan Jenis Kelamin

\begin{tabular}{cccc}
\hline No. & $\begin{array}{c}\text { Jenis } \\
\text { Kelamin }\end{array}$ & $\begin{array}{c}\text { Jumlah } \\
\text { (Responden) }\end{array}$ & $\begin{array}{c}\text { Prosentase } \\
(\%)\end{array}$ \\
\hline 1. & Laki - laki & 8 & 17,8 \\
2. & Perempuan & 37 & 82,2 \\
& Total & $\mathbf{4 5}$ & $\mathbf{1 0 0 \%}$ \\
\hline
\end{tabular}

Sumber: Data Primer Diolah (2017)

\section{Tingkat Usia Responden}

Tingkat usia responden tergolong cukup bervariasi dengan distribusi usia 25 tahun hingga 69 tahun. Jumlah responden tertinggi terdapat pada selang usia 45-49 tahun, yaitu berjumlah 10 orang. Tingkat usia seseorang mencerminkan tingkat kedewasaan orang tersebut dalam mengambil keputusan atau tindakan mengenai hal-hal yang berhubungan dengan dirinya. Perbandingan distribusi usia responden di sekitar mata air Gemulo tahun 2017 dapat dilihat pada Tabel 2.

Tabel 2. Data Jumlah Responden berdasarkan Tingkat Usia Responden

\begin{tabular}{cccc}
\hline No. & Tingkat Usia & $\begin{array}{c}\text { Jumlah } \\
\text { (Responden) }\end{array}$ & $\begin{array}{c}\text { Prosentase } \\
(\%)\end{array}$ \\
\hline 1. & $25-29$ Tahun & 1 & 2,2 \\
2. & $30-34$ Tahun & 4 & 8,9 \\
3. & $35-39$ Tahun & 4 & 8,9
\end{tabular}

\begin{tabular}{cccc} 
4. & $40-44$ Tahun & 6 & 13,4 \\
5. & $45-49$ Tahun & 10 & 22,2 \\
6. & $50-54$ Tahun & 8 & 17,8 \\
7. & $55-59$ Tahun & 6 & 13,3 \\
8. & $60-64$ Tahun & 4 & 8,9 \\
9. & $65-69$ Tahun & 2 & 4,4 \\
\hline & Total & $\mathbf{4 5}$ & $\mathbf{1 0 0} \%$ \\
\hline
\end{tabular}

Sumber: Data Primer Diolah (2017)

\section{Jumlah Tanggungan}

Jumlah tanggungan responden mayoritas berada pada selang 1-6 orang berjumlah 45 responden. Jumlah tanggungan yang dimaksudkan adalah mencakup keluarga inti (anak dan istri/suami) serta tambahan tanggungan bukan keluarga inti yang tinggal dirumah responden maupun tidak tetapi kebutuhannya dibiayai responden. Perbandingan persentase jumlah responden sesuai dengan jumlah tanggungan masing-masing dapat dilihat pada Tabel 3.

Tabel 3. Data Jumlah Responden berdasarkan Jumlah Tanggungan

\begin{tabular}{cccc}
\hline No. & $\begin{array}{c}\text { Jumlah } \\
\text { Tanggungan }\end{array}$ & $\begin{array}{c}\text { Jumlah } \\
\text { (Responden) }\end{array}$ & $\begin{array}{c}\text { Prosentase } \\
(\mathbf{\%})\end{array}$ \\
\hline 1. & 1 Orang & 2 & 4,4 \\
2. & 2 Orang & 15 & 33,3 \\
3. & 3 Orang & 20 & 44,4 \\
4. & 4 Orang & 5 & 11,1 \\
5. & 5 Orang & 3 & 6,7 \\
\hline & Total & $\mathbf{4 5}$ & $\mathbf{1 0 0} \%$ \\
\hline
\end{tabular}

\section{Tingkat Pendidikan Terakhir Responden}

Berdasarkan hasil wawancara dengan responden diperoleh bahwa, tingkat pendidikan terakhir responden didominasi oleh Sekolah Menengah

\begin{tabular}{|c|c|c|c|}
\hline No. & $\begin{array}{c}\text { Tingkat } \\
\text { Pendidikan }\end{array}$ & $\begin{array}{c}\text { Jumlah } \\
\text { (Responden) }\end{array}$ & $\begin{array}{c}\text { Prosentase } \\
(\%)\end{array}$ \\
\hline 1. & SD & 5 & 11,1 \\
\hline 2. & SMP & 16 & 35,6 \\
\hline 3. & SMA & 18 & 40 \\
\hline 4. & PT & 6 & 13,3 \\
\hline 5. & Tidak Sekolah & 0 & 0 \\
\hline & Total & 45 & $100 \%$ \\
\hline
\end{tabular}
Atas (SMA). Perbandingan persentase tingkat pendidikan terakhir responden dapat dilihat pada Tabel 4.

Tabel 4. Data Jumlah Responden berdasarkan Tingkat Pendidikan Formal Terakhir 


\section{Jenis Pekerjaan Responden}

Jenis pekerjaan responden di sekitar mata air Gemulo bervariasi mulai dari petani, guru, swasta, ibu rumah tangga hingga buruh lepas. Mayoritas pekerjaan responden adalah ibu rumah tangga. Hal tersebut disebabkan karena dalam penelitian ini lebih diutamakan ibu rumah tangga untuk memberikan data mengenai jumlah kebutuhan air yang digunakan oleh rumah tangga. Perbandingan persentase jumlah responden pada setiap jenis pekerjaan dapat dilihat pada Tabel 5 .

Tabel 5. Data Jumlah Responden berdasarkan Jenis Pekerjaan Responden

\begin{tabular}{|c|c|c|c|}
\hline No. & $\begin{array}{c}\text { Jenis } \\
\text { Pekerjaan } \\
\end{array}$ & $\begin{array}{c}\text { Jumlah } \\
\text { (Responden) }\end{array}$ & $\begin{array}{c}\text { Prosentase } \\
(\%) \\
\end{array}$ \\
\hline 1. & Petani & 1 & 2,22 \\
\hline 2. & Guru & 5 & 11,1 \\
\hline 3. & Swasta & 4 & 8,8 \\
\hline 4. & $\begin{array}{c}\text { Ibu Rumah } \\
\text { Tangga }\end{array}$ & 30 & 66,6 \\
\hline 5. & $\begin{array}{l}\text { Tukang } \\
\text { Bangunan }\end{array}$ & 1 & 2,22 \\
\hline 6. & Pensiunan & 2 & 4,44 \\
\hline 7. & Karyawan & 1 & 2,22 \\
\hline 8. & Buruh lepas & 1 & 2,22 \\
\hline & Total & 45 & $100 \%$ \\
\hline
\end{tabular}

Sumber: Data Primer Diolah (2017)

\section{Rata-Rata Pendapatan Responden}

Berdasarkan hasil wawancara, dapat dilihat pada Tabel 6bahwa rata-rata pendapatan responden yang paling dominan adalah antara Rp. 1.500.001 - 2.000.000 yaitu sebesar 33,3\% dan pendapatan yang paling jarang adalah Rp. $500.001-1.000 .000$. Hal tersebut menunjukkan bahwa secara ekonomi masyarakat yang bertempat tinggal di sekitar mata air Gemulo dinilai cukup secara finansial.

Tabel 6. Data Jumlah Responden berdasarkan Ratarata Pendapatan

\begin{tabular}{cccc}
\hline No. & Rata-rata Pendapatan & Jumlah & $\%$ \\
\hline 1. & Rp. $500.001-1.000 .000$ & 6 & 13,3 \\
2. & Rp. $1.000 .001-1.500 .000$ & 7 & 15,6 \\
3. & Rp. $1.500 .001-2.000 .000$ & 15 & 33,3 \\
4. & Rp. $2.000 .001-2.500 .000$ & 7 & 15,6 \\
5. & Rp. 2.500.001-3.000.000 & 3 & 6,7 \\
6. & > Rp. 3.000.001 & 7 & 15,6 \\
\hline \multicolumn{4}{c}{ Total } \\
\hline
\end{tabular}

Sumber: Data Primer Diolah (2017)

\section{Analisis Willingness to Pay Masyarakat terhadap Pemanfaatan Mata Air Gemulo}

Dalam penelitian ini digunakan pendekatan CVM untuk menganalisis WTP responden terhadap pembayaran iuran HIPPAM untuk konservasi dan pengelolaan HIPPAM yang memanfaatkan mata air Gemulo. Hasil pelaksanaan CVM adalah sebagai berikut :

\section{A. Membangun Pasar Hipotesis (Setting-up the Hypothetical Market)}

Berdasarkan pasar hipotetik yang telah dibangun pada saat penelitian yaitu dengan memberikan gambaran tentang kondisi lingkungan mata air Gemulo pada saat ini dan di masa yang akan datang mengenai penurunan kualitas dan kuantitas mata air Gemulo yang disebabkan oleh berbagai macam hal, diantaranya adalah terjadinya pertumbuhan penduduk, perubahan penggunaan lahan, peningkatan aktivitas ekonomi, perubahan curah hujan yang akan mempengaruhi jumlah ketersediaan air. Selain itu aktivitas manusia tanpa mempedulikan kondisi sekitar juga turut memberikan ancaman terhadap keberadaan mata air. Sehingga akan berdampak terhadap berkurangnya pasokan air bersih untuk kebutuhan rumah tangga dan rusaknya sistem irigasi pertanian. Dalam hal ini perlu dilakukan upaya konservasi agar kelestarian mata air Gemulo dapat terjaga dengan baik sehingga dapat memberikan dampak positif terhadap kualitas dan kuantitas air yang dihasilkan oleh mata air Gemulo.

\section{B. Memperoleh Nilai WTP (Obtaining Bids)}

Teknik yang digunakan dalam penelitian ini adalah dichotomous choice yaitu menawarkan kepada responden sejumlah uang tertentu untuk mendapatkannilai iuran air bersih per bulan dan menanyakan apakah responden mau membayar atau tidaksejumlah uang tersebut untuk ikut andil dalam upaya perlindungan mataair Gemulo.

\section{Memperoleh Nilai WTP (Obtaining Bids)}

Dugaan nilai WTP (EWTP) responden dihitung berdasarkan data distribusi WTP responden dan dengan menggunakan rumus persamaan (1). Data distribusi WTP responden dapat dilihat pada Tabel 7. 
Tabel 7. Distribusi WTP Responden

\begin{tabular}{|c|c|c|c|c|}
\hline No. & $\begin{array}{c}\text { Kelas } \\
\text { EWTP (Rp/ } \\
\text { KK/Bulan) }\end{array}$ & $\begin{array}{l}\text { Frekuensi } \\
\text { Responden } \\
\text { (Pfi) }\end{array}$ & $\begin{array}{c}\text { Frekuensi } \\
\text { Relatif }\end{array}$ & $\begin{array}{c}\text { Jumlah } \\
\text { (Rp/ } \\
\text { Bulan) }\end{array}$ \\
\hline 1. & 10.000 & 6 & 0,13 & 1.300 \\
\hline 2. & 15.000 & 20 & 0,44 & 6.600 \\
\hline 3. & 20.000 & 10 & 0,22 & 4.400 \\
\hline 4. & 25.000 & 5 & 0,11 & 2.750 \\
\hline 5. & 30.000 & 2 & 0,04 & 1.200 \\
\hline 6. & 35.000 & 1 & 0,02 & 700 \\
\hline \multirow[t]{2}{*}{7.} & 50.000 & 1 & 0,02 & 1.000 \\
\hline & Total & 45 & 1,00 & 17.950 \\
\hline
\end{tabular}

Sumber: Data Primer Diolah (2017)

Kelas WTP responden diperoleh dengan menentukan terlebih dahulu nilai terendah hingga nilai tertinggi WTP yang ditawarkan pada responden. Dari hal tersebut maka diperoleh nilai rataan WTP (EWTP) sebesar Rp. 17.950 untuk tiap Kepala Keluarga tiap bulan.

\section{Memperkirakan Kurva WTP (Estimating Bid Curve)}

Kurva WTP responden berdasarkan nilai WTP responden terhadap jumlah responden yang memilih nilai WTP tersebut. Gambar 1 berikut menjelaskan kurva permintaan WTP terhadap nilai iuran air bersih HIPPAM yang memanfaatkan mata air Gemulo.

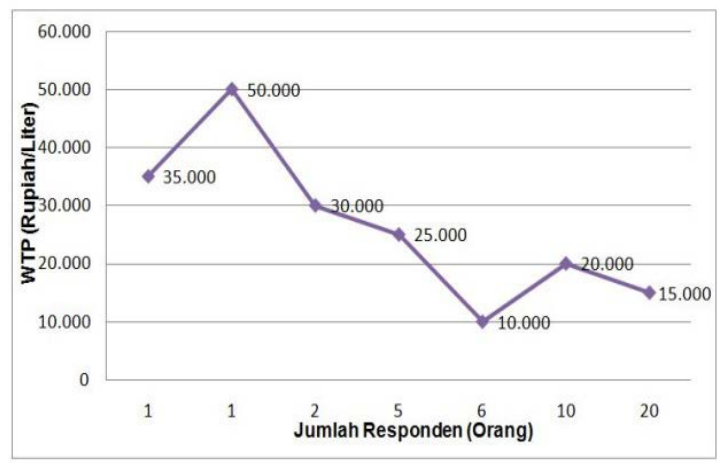

Sumber: Data Primer Diolah (2017)

Gambar 1. Kurva Penawaran WTP terhadap Iuran Pemanfaatan Mata Air Gemulo

Berdasarkan dugaan kurva penawaran WTP dapat dihitung surplus konsumen yang akan diperoleh masyarakat. Surplus konsumen adalah surplus atau kelebihan yang diterima responden karena nilai WTP yang diinginkan lebih tinggi daripada nilai WTP rata-ratanya. Adapun, surplus konsumen responden terhadap nilai iuran air bersih HIPPAM yang memanfaatkan mata air Gemulo adalah sebesar Rp. 22.250/KK/bulan.

\section{E. WTP Agregat atau Total WTP (TWTP)}

Nilai total (TWTP) responden dihitung berdasarkan data distribusi WTP responden Hasil perhitungan TWTP dapat dilihat pada Tabel 8 .

Tabel 8. Total WTP Responden terhadap Iuran Pemanfaatan Mata Air Gemulo

\begin{tabular}{ccccc}
\hline No. & $\begin{array}{c}\text { Kelas WTP } \\
\text { (Rp/KK/ } \\
\text { bulan) }\end{array}$ & $\begin{array}{c}\text { Frekuensi } \\
\text { (Respon- } \\
\text { den) }\end{array}$ & Populasi & $\begin{array}{c}\text { Jumlah } \\
\text { Total }\end{array}$ \\
\hline 1. & 10.000 & 6 & 59,6 & 596.000 \\
2. & 15.000 & 20 & 198,7 & 2.980 .500 \\
3. & 20.000 & 10 & 99,3 & 1.986 .000 \\
4. & 25.000 & 5 & 49,7 & 1.242 .500 \\
5. & 30.000 & 2 & 19,8 & 594.000 \\
6. & 35.000 & 1 & 9,93 & 347.550 \\
7. & 50.000 & 1 & 9,93 & 496.500 \\
\hline & Total & $\mathbf{4 5}$ & $\mathbf{4 4 7}$ & $\mathbf{8 . 2 4 3 . 0 5 0}$ \\
\hline
\end{tabular}

Sumber: Data Primer Diolah (2017)

Berdasarkan hasil perhitungan diperoleh nilai total WTP dari populasi adalah sebesar Rp. $8.243 .050 /$ bulan

\section{F. Evaluasi Pelaksanaan CVM}

Berdasarkan hasil analisis regresi berganda yang diperoleh cukup baik karena dihasilkan nilai $\mathrm{R}^{2}$ sebesar $60,8 \%$. Hal ini sesuai sengan pernyataan Kurniawan (2008) yaitu semakin besar nilai $\mathrm{R}^{2}$ maka semakin baik model regresi yang diperoleh. Namun penelitian ini merupakan penelitian tentang lingkungan yang berhubungan dengan perilaku manusia sehingga nilai $\mathrm{R}^{2}$ tidak harus selalu besar. Mitchell dan Carson (1989) dalam Hanley dan Spash (1993) menyatakan bahwa penelitian yang berkaitan dengan benda lingkungan dapat mentolerir $\mathrm{R}^{2}$ sampai dengan $15 \%$. Oleh karena itu, hasil pelaksanaan CVM dalam penelitian ini masih dapat diyakini kebenaran dan keandalannya. Selain itu nilai koefisien korelasi R adalah 0,786 yang menunjukkan bahwa korelasi dalam persamaan regresi tersebut kuat.

\section{G. Analisis Faktor-Faktor yang Mempenga- ruhi Nilai Willingness to Pay}

Untuk mengetahui faktor-faktor yang mempengaruhi nilai WTP maka telah ditetapkan lima variabel independen yang mempengaruhi variabel dependen yaitu penilaian terhadap tingkat pendidikan (TP), rata-rata pendapatan 
(RPRT), jumlah pemakai air (PA), jumlah kebutuhan air (KA) dan biaya kebutuhan air (BA). Setelah dilakukan uji dengan beberapa pengujian parameter, yaitu uji autokorelasi, uji heterokedastisitas dan uji multikolinearitas tidak ditemukan pelanggaran asumsi klasik terhadap lima variabel independen. Sehingga dalam pengujian berikutnya tetap digunakan lima variabel yang diduga mempengaruhi nilai WTP responden. Tabel 9. berikut merupakan hasil analisis nilai WTP responden

Tabel 9. Hasil Analisis Nilai WTP Responden Mata Air Gemulo

\begin{tabular}{|c|c|c|c|c|}
\hline Variabel & Koefisien & Sig & VIF & Keterangan \\
\hline Constant & 4360,435 & 0,398 & & \\
\hline $\mathrm{TP}$ & $-1155,592$ & 0,284 & 1,529 & $\begin{array}{c}\text { Tidak } \\
\text { berpengaruh }\end{array}$ \\
\hline RPRT & 722,601 & 0,259 & 1,753 & $\begin{array}{c}\text { Tidak } \\
\text { berpengaruh }\end{array}$ \\
\hline PA & 1367,853 & 0,191 & 1,665 & $\begin{array}{c}\text { Tidak } \\
\text { berpengaruh }\end{array}$ \\
\hline KA & $-6305,782$ & 0,062 & 6,586 & $\begin{array}{c}\text { Berpengaruh } \\
\text { nyata }\end{array}$ \\
\hline BKA & 1,767 & 0,000 & 5,683 & $\begin{array}{c}\text { Berpengaruh } \\
\text { nyata }\end{array}$ \\
\hline $\mathbf{R}^{2}$ & 0,608 & & & \\
\hline $\mathbf{F}_{\text {hitums }}$ & 12,116 & & & \\
\hline
\end{tabular}

Model yang dihasilkan dalam penelitian ini cukup baik. Hal ini ditunjukkan oleh $\mathrm{R}^{2}$ sebesar $60,8 \%$, yang berarti $60,8 \%$ keragaman WTP responden dapat diterangkan oleh keragaman variabel-variabel penjelas yang terdapat dalam model, sedangkan sisanya $39,2 \%$ persen diterangkan oleh variabel lain yang tidak terdapat dalam model. Nilai $\mathrm{F}_{\text {hitung }}$ sebesar 12,116 dengan nilai Sig sebesar 0,000, hal ini menunjukkan variabel-variabel penjelas dalam model secara bersama-sama berpengaruh nyata terhadap nilai WTP responden terhadap pembayaran jasa lingkungan yang akan dilakukan pada taraf $\alpha=0,05$. Model yang dihasilkan ini telah diuji multikolinierity, normalitas dan heteroskedastisitas, dari hasil ketiganya tidak diperoleh suatu pelanggaran. Model yang dihasilkan dalam analisis ini adalah :

$\mathrm{WTP}_{\mathrm{i}}=4360,435-6305,782 \mathrm{KA}+1,767 \mathrm{BKA}$
Variabel jumlah kebutuhan air (KA) memiliki nilai Sig 0,062 yang berarti bahwa variabel ini berpengaruh nyata terhadap nilai WTP responden pada taraf $\square 10 \%$. Variabel biaya kebutuhan air (BKA) memiliki nilai Sig 0,000 yang berarti bahwa variabel ini berpengaruh nyata terhadap nilai WTP responden pada taraf $\square 5 \%$. Koefisien yang bertanda positif $(+)$ yaitu, rata-rata pendapatan (RPRT), jumlah pemakaian air (PA), dan biaya kebutuhan air (BKA) berarti bahwa semakin tinggi nilai ketiga variabel tersebut maka semakin besar nilai WTP yang akan diberikan oleh responden. Sedangkan koefisien bertanda negatif (-) pada variabel tingkat pendidikan (TP) dan jumlah kebutuhan air (KA) berarti bahwa semakin rendah kedua variabel tersebut maka semakin besar nilai WTP yang akan diberikan oleh responden.

\section{KESIMPULAN DAN SARAN}

Berdasarkan hasil analisis, diperoleh kesimpulan bahwa semua

responden menyatakan bersedia untuk membayar nilai iuran beserta upaya konservasi yang akan dilakukan di mata air Gemulo. Untuk nilai rataan WTP responden diperoleh sebesar Rp. 17.950 tiap Kepala Keluarga/Bulan dengan nilai total WTP (TWTP) sebesar Rp. 8.243.050/ bulan. Nilai rataan WTP tersebut lebih besar jika dibandingkan dengan tarif air rata-rata yang diterapkan oleh HIPPAM Cangar pada saat ini, yaitu Rp. $9.931 \mathrm{KK} /$ bulan. Selain menunjukkan adanya kepedulian responden yang tinggi terhadap upaya kelestarian mata air Gemulo, juga karena tingginya kepuasaan pelanggan (utilitas) terhadap barang atau jasa yang diterima. Dalam penelitian ini responden mengganggap peranan air merupakan hal paling penting yang tidak bisa digantikan dengan barang apapun sehingga keberlanjutan ketersediaan air bersih, baik secara kualitas dan kuantitas wajib dijaga dengan baik, salah satunya adalah dengan upaya konservasi mata air Gemulo.

Terdapat beberapa variabel yang berpengaruh secara signifikan terhadap besaran nilai WTP, yaitu:

Pertama, Variabel jumlah kebutuhan air, semakin rendah jumlah kebutuhan air semakin 
berpengaruh terhadap nilai WTP. Mengingat tingginya kepedulian warga terhadap kelestarian mata air dan karena air merupakan kebutuhan paling mendasar untuk makhluk hidup maka sekecil apapun jumlah kebutuhan air responden akan mempengaruhi nilai WTP pemanfaatan air.

Kedua, Variabel biaya kebutuhan air, semakin tinggi biaya kebutuhan air semakin berpengaruh terhadap nilai WTP. Biaya air menjadi tolak ukur kemampuan responden untuk memberikan nilai WTP, semakin besar biaya kebutuhan air maka semakin besar pula tawaran untuk nilai WTP yang diberikan, sehingga biaya kebutuhan air akan meningkat seiring dengan nilai WTP yang diberikan.

Ketiga, Variabel tingkat pendidikan, ratarata pendapatan dan jumlah pemakai air tidak berpengaruh terhadap nilai WTP pemanfaatan mata air Gemulo. Hal ini dikarenakan dalam memberikan nilai WTP responden tidak mempedulikan lagi bagaimana latar belakang pendidikan, pendapatan dan jumlah pemakai air dalam rumah tangga. Bagi warga, terpenuhinya kebutuhan air bersih jauh lebih penting bagi kelangsungan hidup sehari-hari.

Dengan hasil penelitian diatas, maka hal yang perlu dilakukan adalah:

Pertama, diperlukan sosialisasi oleh pengelola atau pengurus HIPPAM kepada warga sekitar akan pentingnya peranan air dalam kehidupan sehari-hari, hal ini dimaksudkan agar dapat meningkatkankesadaran warga terhadap upaya pelestarian mata air.

Kedua, besarnya nilai WTP responden dapat dijadikan bahan pertimbangan dalam penetapan iuran air bersih HIPPAM Cangar. Dimana pengelola HIPPAM dapat menaikkan tarif air bersih, namun masih dalam batas kemampuan warga untuk membayar iuran. Dengan adanya peningkatan tarif air bersih oleh pengelola HIPPAM diharapkan dapat digunakan untuk upaya pelestarian mata air Gemulo dalam bentuk konservasi, dimana mata air Gemulo merupakan satu-satunya sumber air yang dimanfaatkan oleh warga Dusun Cangar.

Ketiga, HIPPAM harus dapat memperbaiki dan meningkatkan manajemen pengelolaan HIPPAM seiring dengan kenaikan tarif, sehingga dana iuran yang terkumpul dari masyarakat untuk air bersih dapat dioptimalkan serta peningkatan pelayanan (perbaikan kerusakan pipa, peningkatan jumlah debit air, peningkatan kualitas air dan kelancaran distribusi air) dapat berjalan dengan baik. Selain itu, iuran yang diperoleh dapat dipergunakan untuk meningkatkan kesejahteraan para pengurus HIPPAM, mengingat selama ini pengurus HIPPAM bekerja secara sukarela tanpa memperoleh insentif bulanan. Peningkatan kesejahteraan para pengelola HIPPAM penting untuk dipertimbangkan mengingat HIPPAM merupakan satu-satunya pihak yang menyediakan jasa air bersih untuk masyarakat Dusun Cangar sehingga diperlukan keberlanjutan operasional HIPPAM penting untuk dilakukan.

\section{DAFTAR PUSTAKA}

Dasrizal, Ansofino, Erna Juita dan Jolianis. (2012). Model Sistem Pembayaran Jasa Lingkungan Dalam Kaitannya Dengan Konservasi Sumberdaya Air dan Lahan: Studi Kasus Pada Batang Anai Sumatera Barat. Journal of Economic and Economic Education, Vol.1 No.1 (16-31).

Fauzi, Akhmad. (2004). Ekonomi Sumber Daya Alam dan Lingkungan. Jakarta: Gramedia Pustaka Utama.

Hanley, Nick., \& Spash, Clive. L. (1993). Cost-Benefit Analysis. USA: Edward Elgar Publishers.

Juanda, Bambang. (2009). Ekonometrika: Pemodelan dan Pendugaan. Bogor: IPB Press.

Masduqi. Ali, Endah dan Soedjono, Eddy. S. (2008). Sistem Penyediaan Air Bersih Pedesaan Berbasis Masyarakat: Studi Kasus HIPPAM di DAS Brantas Bagian Hilir dalam Seminar Nasional Pascasarjana VIII. Surabaya: Institut Teknologi Surabaya.

Mitchell, R.C., \& Carson, R.T. (1989). Using Surveys to Value Public Goods - the Contingent Valuation Method. USA, Washington: Resource for the Future.

Nazir. (1998). Metode Penelitian. Jakarta: Ghalia Indonesia. 
Rizal, Muhammad. R. (2010). Tinjauan Pustaka

Air. Diambil dari https://www.academia. edu/11664271/Tinjauan_Pustaka_Air. [diakses 01 Juli 2017].
Suparmoko, M. (1994). Ekonomi Sumberdaya Alam dan Lingkungan, Suatu Pendekatan Teoritis Edisi 3. Yogyakarta: BPFE. 